\title{
PEMANFAATAN GIIS UNTUK PELESTARIAN SITUS-SITUS SEKITAR BOROBUDUR
}

\author{
Oleh: Yudi Suhartono, SS \\ Koordinator Pokja Dokumentasi \\ Balai Konservasi Peninggalan Borobudur
}

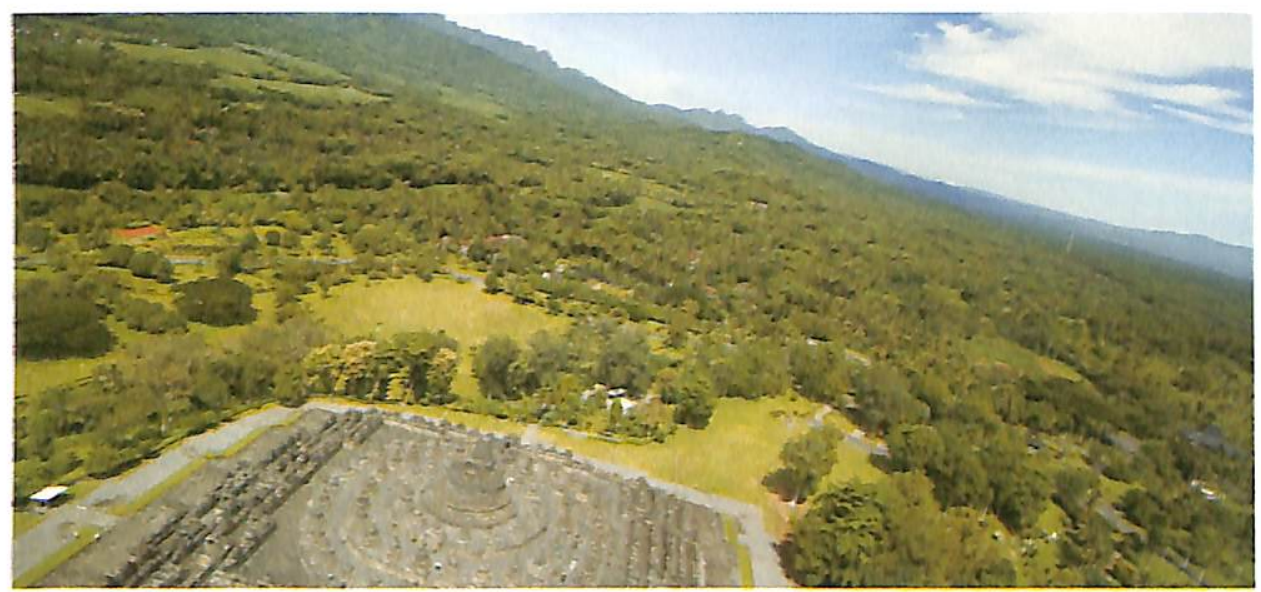

GIS adalah sistem komputer yang terdiri dari perangkat keras, perangkat lunak dan personal (manusia) yang dirancang secara efisien memasukkan, menyimpan, memperbaharui, manipulasi, menganalisa dan menyajikan untuk semua informasi yang berorientasi geografis (Aronoff, 1989).

Geographic information system menyajikan informasi spasial memakai lokasi, dalam suatu sistem koordinat tertentu, sebagai dasar referensinya. Karenanya GIS mempunyai kemampuan untuk menghubungkan berbagai data pada suatu titik tertentu di bumi, menggabungkannya, menganalisa dan akhirnya memetakan hasilnya. Aplikasi GIS mampu menjawab beberapa pertanyaan seperti: lokasi, kondisi, trend, pola, dan pemodelan. Kemampuan inilah yang membedakan GIS dari sistem informasi lainnya. (Puntadewa, dkk, $20(03: 9)$

GIS mampu membuat (menggambarkan) peta dengan lebih fleksibel, bahkan dibanding dengan menggambar peta secara manual, atau dengan pendekatan kartografi yang scrba otomatis. Dimulai dengan membuat database, gambar peta yang sudah ada bisa digambar dengan digitizer dan informasi tertentu, kemudian bisa diterjemahkan ke dalam GIS. Database kartografi berbasis GIS dapat bersambungan dan bebas skala. Peta-peta kemudian bisa diciptakan terpusat di berbagai lokasi, dengan sembarang skala, dan menunjukkan informasi terpilih, yang mencerminkan secara efektif untuk menjelaskan suatu karakteristik khusus.

Kemampuan tersebut membuat sistem informasi GIS berbeda dengan sistem informasi pada umumnya. Informasi dari GIS mampu untuk memberikan penjelasan tentang suatu peristiwa, membuat peramalan kejadian, dan perencanaan strategis lainnya. Oleh kemampuannya tersebut, aplikasi GIS telah banyak digunakan pada sektor-sektor yang bersetuhan langsung dengan dinamika dan problematika kehidupan seperti masalah pengelolaan lingkungan, kependudukan, perencanaan wilayah, pertanahan, pariwisata, ekonomi, bisnis, marketing, telokomunikasi, transportasi, navigasi, militer dan lain sebagainya termasuk untuk pelestarian Sumberdaya arkeologi.

\section{Geographic Information System (GIS) adalah suatu sistem berbasis komputer yang me mp и nу а $i$ kem a mpuan da lam pamasukkan, pengambilan, analisis data dan tampilan data geografis yang sangat penting bagi pengambilan keputusan.}

Pembangunan dan pelestarian sumberdaya arkeologi

Pembangunan dapat diartikan sebagai suatu usaha perubahan dari suatu keadaan dan kondisi ke masyarakat tertentu kepada suatu keadaan dan kondisi ke masyarakat yang dianggap lebih baik atau yang diinginkan. Pembangunan di Indonesia, dilakukan di segala bidang meliputi pembangunan berbagai sektor seperti, ilmu pengetahuan dan teknologi, ideologi, sosial, budaya, politik, dan hankam. Khusus pembangunan di bidang kebudayaan adalah termasuk pengelolaan sumber daya arkeologi atau dalam Undangundang RI No, 5 tahun 1992 disebut benda cagar budaya dan situsnya. Untuk menunjang keberhasilan pembangunan itu segala sumberdaya yang ada harus dimanfaatkan dan dikelola dengan serasi, seimbang dan selaras untuk kemanfaatan masyarakat dalam arti luas. Sumberdaya itu meliputi sumber daya manusia, sumber daya alam, sumber daya buatan dan sumber daya budaya (arkeologi) (Kusumohartono, 1995: 5). Semuanya itu bertujuan untuk meningkatkan kesejahteraan rakyat dan mengejar ketinggalan dengan negara-negara lain yang sudah maju. 
Pada kenyataaannya dari berbagai bidang pembangunan tersebut, terlihat bahwa pembangunan yang dilakukan masih menprioritaskan pada pembangunan bidang sarana fisik yang menekankan pada peningkatan ekonomi.

Pelestarian sumber daya arkeologi sering berbenturan dengan pembangunan di bidang prasarana fisik tersebut. Pembangunan bidang sarana fisik sering berdampak negatif bagi upaya pelestarian sumberdaya arkeologi. Rencana pengembangan kota atau wilayah masih sering mengabaikan keberadaan sumberdaya arkeologi, pendirian pabrik-pabrik, pembangunan waduk, pembangunan jalan tol seringkali terpaksa menghancurkan, memusnahkan atau menenggelamkan sumberdaya arkcologi yang ada. Dengan demikian pembangunan sering dianggap negatif bagi pelestarian sumber daya arkeologi, apakah selalu demikian dan tidak ada jalan pemecahan yang bisa mempertemukan kedua belah pihak untuk mengurangi dampak negatif yang ditimbulkan oleh pembangunan pada pelestarian sumber daya arkeologi (Tjahjono, 1996:40).

Pembangunan dan pelestarian situs-situs di sekitar Borobudur

Keberhasilan pemugaran Candi Borobudur telah mengangkat Indonesia sebagai salah satu bangsa yang dianggap cukup berhasil dalam pelestarian warisan budaya. Sejak diresmikannya purna pugar tahun 1983, Candi Borobudur semakin ramai dikunjungi oleh wisatawan, baik wisatawan Nusantara maupun wisatawan manca negara yang ingin secara langsung melihat keindahan Candi Borobudur

Banyaknya wisatawan yang mengunjungi candi Borobudur menyebabkan Borobudur menjadi pusat perhatian dari pemerintah dan kemudian menjadikan candi Borobudur sebagai Taman Wisata dengan mendirikan perusahaan perseroan Taman Wisata Candi Borobudur dan Prambanan sebagai pengelola lingkungan khususnya zone 2 kawasan Borobudur pada tahun
1980. Dengan dibentuknya PT. Taman Wisata Candi Borobudur dan Prambanan, dimulailah pembangunan di kawasan Borobudur.

Dengan dibangunnya Taman Wisata Candi Borobudur otomatis membutuhkan lahan yang luas sekitar $82,4 \mathrm{Ha}$. Hal ini membuat masyarakat yang tinggal di sekitar candi Borobudur harus rela meninggalkan rumahnya dan pindah agak jauh dari Candi Borobudur yang selama ini mereka tempati. Dari data yang ada, diketahui bahwa di lokasi taman wisata ini terdapat beberapa dusun yang berada dalam wilayah Desa Borobudur. Dusun-dusun antara lain Ngaran dan Kenayan. Dusun-dusun tersebut kemudian dipindahkan ke luar kompleks Taman Wisata candi Borobudur. Pemindahan penduduk tersebut dengan dua cara, yang pertama berpindah penduduk ke dusun-dusun sekitar yang tidak tergusur dan kedua, membentuk kapling/dusun baru ke lokasi yang sebelumnya berupa hutan/lahan kosong, yang sekarang masuk zona 3 Borobudur. Dusun-dusun baru tersebut adalah Kenayan, Kapling Jayan, Kapling Janan dan Kapling Jligudan. Selain perpindahan penduduk, pembuatan Taman wisata juga berdampak pada pemindahan sarana dan fasilitas umum seperti pasar, kantor camat dan lain sebagainya, yang sebelumnya berada di lokasi tersebut. Perpindahan dusundusun dan fasilitas umum tersebut tentunya membutuhkan areal baru yang cukup luas dan hal demikian sebenarnya sangat riskan mengingat lingkungan candi Borobudur juga merupakan situs dan diduga banyak mengandung temuan arkeologi dan telah dicatatkan dalam laporan yang dibuat pada masa pemerintahan Hindia Belanda.

Dalam laporan tersebut dapat diketahui bahwa di sekitar Candi Borobudur yang bersifat Buddha terdapat candi-candi yang bersifat Hindu (N.J. Krom, 19i4:211-277). Laporan Belanda yang disusun dalam buku Rapporten ran den ()ubreidkandigen Dienst in Nederlandsch Indie (R( D) 1914 mentebutkan adanya beberapa candi
Hindu di selitar Candi Borobudur. Di dalam buku tersebut dilaporkan adanya temuan-temuan arkeologis di daerah Magelang, seperti candi Borobudur, candi Pawon, candi Mendut, candi Banon serta arca-arca dewa Hindu dan Buddha baik dari batu maupun perunggu.

Namun sayang sekali, dalam pemindahan dusun-dusun dan fasilitas umum ke lokasi yang baru tidak disertai dengan penelitian arkeologi, dibuktikan dengan tidak adanya laporan arkeologi mengenai hal tersebut. Jika dilihat dari sejarah kawasan Borobudur yang merupakan daerah kekuasan Mataram kuna pada sekitar abad VII - X M memungkinkan kawasan ini mengandung sumberdara arkeologi yang cukup padat. Hal ini telah dibuktikan pada penelitian yang dilakukan oleh beberapa penelitian di antaranya Wiwit Kasiati, dkk (1992) dan Yudi Suhartono, dkk (2003). Hasil penelitian tersebut menunjukkan bahwa di sekitar kawasan Borobudur terdapat banyak situs-situs yang mengelilingi candi Borobudur baik itu situs bercirikan agama Buddha maupun agama Hindu.

Perkembangan pembangunan di sekitar candi Borobudur, juga diikuti dengan perpindahan ibu kota kabupaten Magelang pada tahun 1982 dari Muntilan ke Mungkid vang hanya berjarak sekitar $2,5 \mathrm{~km}$ dari candi Borobudur dan termasuk dalam kawasan Borobudur (Ninarni, 2006: 93). Pemindahan ibukota kabupaten Magelang berarti juga membutuhkan lahan baru untuk pembangunan perkantoran, pemukiman, tempat usaha dan berbagai jenis aktivitas ekonomi lainnya. Sama halnya dengan pemindahan lokasi pemukiman saat pembangunan PT. Taman Wisata Candi Borobudur yang tanpa disertai dengan penlitian arkeologi, hal ini juga terjadi pada pembangunan fasiltas ibu kota Magelang di Mungkid yang tidak disertai dengan penelitian arkerologi. yang dibuktikan dengan tidak ditemukanya laporan arkeologi mengenai hal tersebut. 
Dengan berkembangnya Kawasan Borobudur menjadi daerah pariwisata yang potensial menyebabkan kebutuhan lahan sangat besar untuk pembangunan fasilitas pendukung pariwisata seperti bangunan hotel, restoran, pertokoan dan lain sebagainya di kawasan tersebut. Pembangunan berbagai fasilitas pariwisata tentunya juga membutuhkan lahan baru, yang jika tidak di kontrol akan mengganggu keberadaan situs-situs arkeologi yang ada. Tulisan di atas bukan bermaksud untuk menyudutkan para pengambil keputusan pada masa lalu, tetapi hal tersebut dapat dijadikan masukan betapa pentingnya informasi mengenai keberadaan situs-situs arkeologi di kawasan Borobudur. Informasiinformasi mengenai situs-situs tersebut sangat dibutuhkan sebagai pertimbangan untuk pengembangan kawasan Borobudur di masa yang akan datang.

Pemanfaatan GIS untuk pelestarian situs-situs di sekitar Borobudur

Pemanfaatan GIS di Indonesia telah banyak dipergunakan untuk membantu pelestarian sumberdaya arkeologi, antara lain penggunaan GIS untuk pelestarian situs-situs di propinsi Jambi, Yogakarta dan lain sebagainya. Alat bantu GIS dipilih karena memiliki kemampuan untuk mengolah data spasial yang lengkap dan terperinci. Selain itu GIS juga mampu menggabungkan semua kemampuan, baik yang hanya berupa sekedar tampilan saja, sistem informasi yang tersaji secara thematis, dan sistem pemetaan yang berdasarkan persebaran situs yang ada, bersamaan dengan kemampuan untuk menganalisa lokasi geografis dan informasi tertentu yang terkait terhadap lokasi yang bersangkutan.

Dengan menggunakan aplikasi GIS, kita dapat memetakan situs-situs di kawasan Borobudur lengkap dengan keletakan koordinat UTM dan informasi lainnya. GIS adalah sebuah aplikasi dinamis, dan akan terus berkembang.
Peta yang dibuat pada aplikasi ini tidak hanya akan berhenti dan terbatas untuk keperluan saat dibuatnya saja. Dengan mudahnya kita bisa melakukan peremajaan terhadap informasi yang terkait pada peta tersebut, dan secara otomatis peta tersebut akan segera menunjukkan akan adanya perubahan informasi tadi. Dengan demikian data-data tentang situs-situs di sekitar Borobudur akan diperbaharui setiap waktu sehingga kondisi situs-situs akan diketahui jika terjadi perubahan tata guna lahannya.

Selain inforamsi situs dengan data yang lengkap, dalam kaitannya dengan pemanfaatan lahan di kawasan Borobudur, GIS juga bisa menampilkan tata guna lahan yang ada di kawasan tersebut. Dengan informasi tata guna lahan ini, dapat diketahui arah perkembangan suatu pemukiman penduduk sehingga dapat diantisipasi kemungkinan-kemungkinan yang terjadi yang akan mengancam kelestarian situs. Tata guna lahan ini kemudian akan digabungkan dengan persebaran situs yang ada di kawasan Borobudur untuk melihat keletakan situs-situs dalam peta tata guna lahan, kemudian akan dianalisis untuk melihat sejauh mana perkembangan lahan di kawasan Borobudur yang dapat mengacam keberadaan situssitus yang ada.

Hasil penggabungan peta persebaran situs dengan peta tata guna lahan bisa digunakan sebagai bahan untuk negosiasi dengan pihak-pihak yang berkepentingan dalam pembangunan kawasan Borobudur seperti pemerintah daerah kabupaten Magelang dan instansi terkait lainnya. Perlu diketahui, perencanaan pembangunan di kabupaten Magelang khususnya di kawasan Borobudur telah dituangkan dalam dalam Rencana Tata Ruang Wilayah (RTRW) kabupaten Magelang dan Rencana Umum Tata Ruang (RUTR) kota Mungkid.

Untuk mengantisipasi dampak pembangunan yang ditimbulkan seperti yang direncanakan dalam Rencana Tata Ruang Wilayah (RTRW) kabupaten Magelang dan Rencana
Umum Tata Ruang (RUTR) kota Mungkid terhadap situs-situs yang ada di kawasan Borobudur, perlu diberikan informasi mengenai keberadaan situssitus kepada para pengambil kebijakan di kabupaten Magelang. Informasi ini tidak hanya sekedar peta persebaran situs, tetapi juga diberikan informasiinformasi lainnya yang mendukung seperti informasi tata guna lahan, demografi, potensi pariwisata dan informasi geografis lainnya. Untuk itu hasil dari aplikasi GIS di kawasan Borobudur yang telah lengkap informasinya, dapat digunakan sebagai alat bantu untuk 'melobi" para pengambil kebijakan supaya dalam melaksanakan pembangunan, tetap memperhatikan keberadaan situs-situs arkeologi yang cukup banyak di wilayah tersebut, sehingga kasus-kasus "penggusuran" situs-situs arkeologi akibat pembangunan dapat dicegah dan tidak terulang lagi seperti yang terjadi di masa lalu. Namun perlu ditekankan dalam hal ini, bahwa hasil aplikasi GIS ini hanya sebuah alat, kepandaian "melobi" dari pimpinan instansi yang bertanggung jawab terhadap kelestarian sumberdaya arkeologi sangat diperlukan dan menjadi faktor yang cukup menentukan. Dalam "melobi" dan negosiasi tersebut, perlu juga dipersiapkan perangkat-perangkat hukum yang dapat melindungi keberadaan sumberdaya arkeologi yang ada.

Hal-hal yang telah disebutkan di atas hanya merupakan sedikit dari pemanfaatan GIS untuk pelestarian situs-situs. Namun demikian, uraian di atas diharapkan bisa membantu "menjembati" permasalahan yang terjadi antara pembangunan sarana fisik dan pelestarian sumberdaya arkeologi di kawasan Borobudur. $₫$ 


\section{DAFTAR PUSTAKA}

Aronaff, 1989. G e o $\mathrm{g} \mathrm{r}$ a $\mathrm{p} \mathrm{h}$ i c Information System : A Management Perspective. Ottawa Kanada : WDL Publication.

Drajat, Hari Untoro, 1995. "Manajemen Sumber Daya Budaya Mati" dalam Seminar Nasional Metodologi Riset Arkeologi. Depok Jurusan Arkeologi, Fakultas Sastra Universitas Indonesia.

Karyawan, Budi, 2000. "Pemetaan Digital" dalam Buletin Cagar Budaya, Vol. 1 No. 2 Juli Jakarta : Direktorat Purbakala

Kasiati, Wiwit, dkk, 2002. Candicandi Hindu Di Sekitar Borobudur. Borobudur : BSKB.

Kusumohartono, Bugie, 1993. "Penelitian Arkeologi d a 1 a m Ko n t e k s Pengembangan Sumber Daya Arkeologi", Berkala Arkeologi, Nomor 2 Maret. Jogyakarta : Balai Arkeologi.
Krom, N.J, 1914. Repporter Van Den Oudheidkundige in Neder Landsch Indie. Inventaris der Hindoeoudheden. Batavia, Gravenhage: M. Nijhoff.

Puntadewo, Atie, dkk, 2002. Sistem Informasi Geografis Untuk Pengelolaan Sumber Daya Alam. Jakarta : Center For International Forestry Research.

SA, Nugroho, 2000. "Pemlotan Situs" dalam Buletin Cagar Budaya, Vol. 1 No. 2 Juli. Jakarta : Direktorat Purbakala

Sutopo, Marsis, 1998. "Sistem Informasi Geografis Untuk Pembuatan Peta Distribusi Situs" dalam Bulletin Arkeologi Amoghapasa 6/III/Maret. Batusangkar : SPSP Sumbar dan Riau.

Suhartono, Yudi, dkk, 2003. Studi Arkeologi Yoni-yoni d i S e kitar C a n d i Borobudur.Borobudur : BSKB.
Taufik, Muhammad

2004.

Minimalisasi Dampak

Negatif Pemanfaatan Candi Borobudur Sebagai Objek wisata. Tesis Program Studi Arkeologi, Bidang Ilmu Humaniora, Program Pasca Sarjana, Universitas Gajah Mada. Jogyakarta.

Tjahjono, Baskoro Daru, 1996. "Pemikiran Inklusif Atas Dampak Pembangunan Terhadap Kelestarian Sumberdaya Arkeologi" Berkala Arkeologi No. 1 Tahun XVI. Jogyakarta : Balai Arkelogi.

Winarni 2006. Kajian Perubahan

Ruang Kawasan World Cultural Heritage Candi Borobudur. Tesis Magister Perencanaan Kota dan Daerah. Yogyakarta : Sekolah Pasca Sarjana UGM.

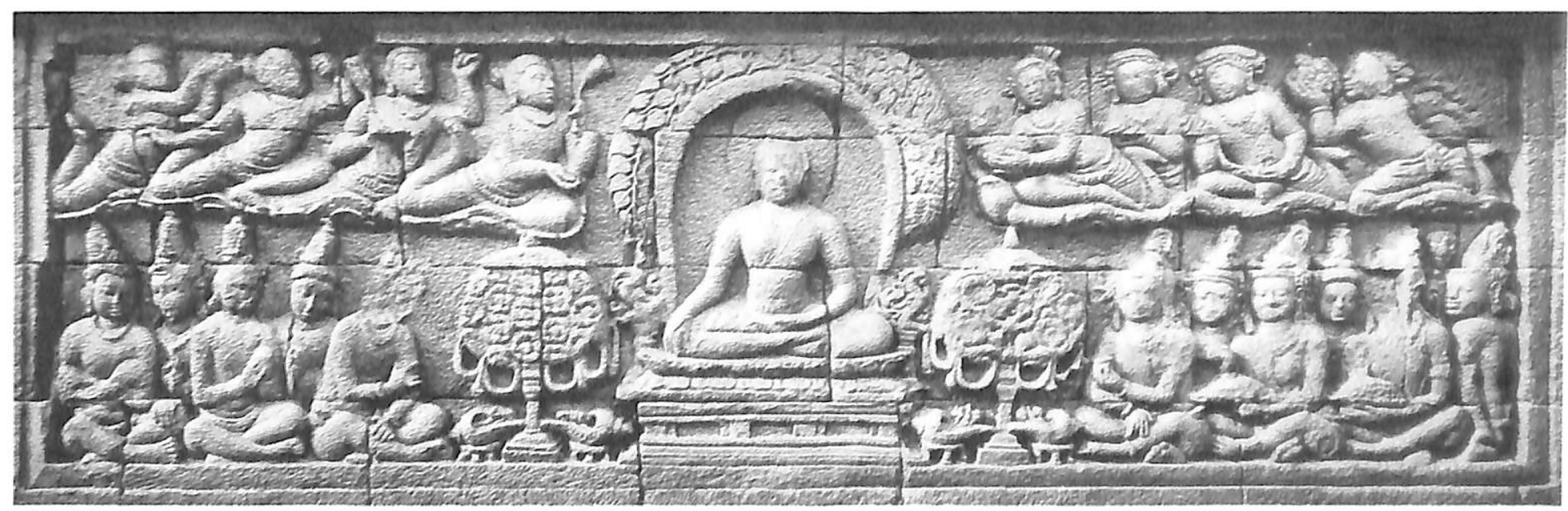

Relief :

Setelah melalui berbagai rintangan

akhirnya Pangeran Sidharta mencapai pengetahuan tertinggi dan menjadi Budha.

Lokasi :

Sisi Utara, Dinding Tingkat I relief rangkaian atas bidang $\mathrm{h}$ 